\title{
426. Korrekturosteotomie des distalen Speichenendes mit der Radiuszinkenplatte
}

\author{
K. D. Moser \\ Unfallkrankenhaus Linz (Leiter: Prim. Dr. R. Streli), A-4010 Linz
}

\section{Osteotomy and Fork-Plate Stabilization after Colles' Fracture}

\begin{abstract}
Summary. Fork-plate stabilization after osteotomy of the distal end of the radius is an effective method of fixation. The connection between the plate and the prongs is stable and the prongs are tilted a little $\left(10^{\circ}\right)$ to the palmar aspect. The prongs are inserted after predrilling of the holes for the prongs about 5 mm proximal to the articular surface. Usually we pack the secondary defect in the radius firmly with homologous deep-frozen cancellated bone. External fixation is not necessary.
\end{abstract}

Key words: Osteotomy - Colles' fracture - Fork-plate.

Zusammenfassung. Die Radiuszinkenplatte stellt eine ausgezeichnete Osteosynthese bei Korrekturosteotomien des distalen Radiusendes dar. Zwischen Platte und Zinken besteht eine feste Verbindung und die Zinken sind $10^{\circ}$ zur Beugeseite geneigt. Nach Vorbohrung der Löcher für die Zinken, ca. $5 \mathrm{~mm}$ proximal der Radiusgelenkfläche, wird die Platte eingeschlagen. Der durch die Osteotomie entstandene Sekundärdefekt wird mit homoiologer, kältekonservierter Spongiosa aufgefüllt. Die Osteosynthese ist übungsstabil und auf eine äußere Fixation kann verzichtet werden.

Schlïsselwörter: Osteotomie - Distaler Radius - Radiuszinkenplatte.

\section{Verhalten autologer mikrochirurgischer Arterien- und Veneninterponate im wachsenden Organismus}

\author{
P. M. Münch, M. Palm und L. Zwank \\ Kliniken der Stadt Saarbrücken, Winterberg, Chirurgische Klinik, D-6600 Saarbrücken
}

\section{Behaviour of Autologous Microsurgical Arterial and Venous Grafts in the Growing Organism}

Summary. In this experiment arterial grafts were implanted in 24 young rats and venous grafts in 25 animals. The average increase in length of the grafts was $76.6 \%$ for arteries and $50.8 \%$ for veins after a mean of 263 days. The patency rate of the grafts was $95.6 \%$, and that of the venous grafts $84 \%$. There were aneurysmal changes in $43 \%$ of the venous grafts, but no such changes were found with the arterial grafts. The anastomotic sites showed no stenosing alterations. According to our measurements the implanted grafts develop in keeping with the total organism.

Key words: Microsurgery - Vascular grafts - Growth of vascular grafts - Aneurysms.

Zusammenfassung. In diesem Experiment wurde 24 jungen Ratten ein Arterien- und 25 Tieren ein Veneninterponat implantiert. Die durchschnittliche Längenzunahme der Interponate, nach im Mittel 263 Tagen, betrug 76,6\% bei Arterien und $50,8 \%$ bei Venen. Die Durchgängigkeitsrate der Arterieninterponate betrug $95,6 \%$, die der Venen $84 \%$. Aneurysmatische Veränderungen traten bei Veneninterponaten in $43 \%$, bei Arterien in keinem Fall auf. Die Anastomosenstellen zeigten keine stenosierenden Veränderungen. Nach unseren Messungen erfahren die implantierten Interponate eine der dem Gesamtorganismus entsprechende Entwicklung.

Schlüsselwörter: Mikrochirurgie - Gefäßinterponate - Interponatwachstum - Aneurysmen. 